ROCZNIKI TEOLOGICZNE

Tom LXVIII, zeszyt 3 - 2021

DOI: https://doi.org/10.18290/rt.21683-4

ANDRZEJ DERDZIUK OFMCap

\title{
KS. IRENEUSZ MROCZKOWSKI (1949-2020) TEOLOG MORALISTA
}

\author{
Fr. IRENEUSZ MROCZKOWSKI (1949-2020) THE MORAL THEOLOGIAN
}

A b s t r a c t. Fr. Ireneusz Mroczkowski (1949-2020) was a moral theologian employed at the Catholic University of Lublin and at the Cardinal Stefan Wyszyński University and other academic schools. He was an active participant in the life of the Church in Płock as the rector of the seminary, member of the Płock Scientific Society and editor of Studies in Płock. He served as chairman of the Association of Moral Theologians in Poland. In his scientific work, he dealt with the methodology of moral theology, anthropology, theology of the body, marriage and family, feminism, human rights, morality of socio-political life and ecology. He also spoke about the issues of seminary education, the condition of the Church in Poland, the vocation and mission of lay people in the contemporary Church and the current state of moral awareness. He was a good man who combined simple faith with the discipline of reason and honesty of heart.

Keywords: Ireneusz Mroczkowski; moral theology; history of moral theology; anthropology.

Powołaniem teologa moralisty jest czytelne przekazywanie Bożego orędzia, które może ożywiać postępowanie uczniów Chrystusa. Winien on nie tylko zgłębiać mądrość Pisma Świętego i nauczania Kościoła, ale też doświadczać osobistego spotkania z Chrystusem, by dawać świadectwo swojego zakorzenienia we wspólnocie wiary. Postać ks. profesora Ireneusza Mroczkowskiego

Prof. dr hab. ANDRZEJ DERDZIUK OFMCap - Sekcja Teologii Moralnej, Instytut Nauk Teologicznych na Wydziale Teologii Katolickiego Uniwersytetu Lubelskiego Jana Pawła II; adres do korespondencji: Al. Racławickie 14, 20-950 Lublin; e-mail: andrzej.derdziuk@kul.pl; ORCID: https://orcid.org/0000-0003-4678-726X. 
(1949-2020) zasługuje na utrwalenie w pamięci potomnych, gdyż był on autentycznym świadkiem wiary i mądrym myślicielem podejmującym twórczą refleksję na moralnym przesłaniem Kościoła.

Ks. Mroczkowski wraz z ks. prof. Januszem Nagórnym (1950-2006) stanowili tandem doskonale się uzupełniających teologów moralistów, którzy pracując razem w Instytucie Teologii Moralnej KUL i działając w ramach Stowarzyszenia Teologów Moralistów w Polsce, ożywiali środowisko teologów swoją twórczą myślą oraz oryginalnym podejściem do zagadnień teologicznomoralnych. Nagórny prezentował via descendens, która od Bożego Logosu zniżała się do świata, oświetlając go światłem Bożej mądrości. Z kolei Mroczkowski, ze swoim zmysłem egzystencjalnego wnikania w meandry ludzkich losów i ich wewnętrznych motywacji, szukał tego, czym dzisiaj żyje człowiek i niejako indukcyjnie dochodził do ogólnych stwierdzeń o aktualnej kondycji ludzkości. Jego via ascendens była pokornym wznoszeniem się ku górze, w przekonaniu, że w świecie jest dużo dobra, ale trzeba je odkryć i wydobyć.

W niniejszym tekście zostanie przedstawiona biografia Profesora z Płocka, etapy posługi kapłańskiej oraz jego zaangażowanie w sprawy Kościoła i sylwetka naukowa. Przedmiotem badań będą zakresy twórczości naukowej i organizacyjnej, które rozwijał w swoim życiu wypełnionym posługą na różnych polach działalności naukowej i duszpasterskiej.

\section{DZIECIŃSTWO I OKRES FORMACJI DO KAPŁAŃSTWA}

Ireneusz Mroczkowski urodził się 24 grudnia 1949 r. w Makowie Mazowieckim i wraz ze swoim bratem wychowywał się w Gardziołkach, przysiółku wsi Boruty w gminie Rzewnie. Rodzice Ireneusza: Weronika z domu Szubińska i Edward Mroczkowscy byli właścicielami gospodarstwa rolnego i zajmowali się uprawą ziemi. Swoje dzieci wysyłali najpierw do Szkoły Podstawowej w Rzewniu, odległej o 2 kilometry od domu, co wiązało się z koniecznością pokonywania drogi pieszo. Ireneusz rozpoczął naukę 1 września 1956 pod opieką pani Reczek, wychowawczyni I klasy. Rodzice marzyli o rozwoju swoich synów i wpajali im nade wszystko wartości wiary i miłości. Tak po latach ujął to ks. Mroczkowski: „Mój ojciec, tym bardziej mama, nie opowiadali mnie i mojemu bratu o tym, kim możemy zostać w życiu. Ale w istocie budzili tę samą siłę woli, która pozwala skorzystać z szansy, jaką daje szkoła. Nie skupiali się na tym, czego nam brakuje, albo co mają inni, ale uczyli wiary w to, co może być. Nieustannie też budowali szacunek 
dla nauczycieli" . Obaj synowie państwa Mroczkowskich zdobyli wyższe wykształcenie i uzyskali tytuły profesorskie.

W 1958 r. Ireneusz przyjął Pierwszą Komunię świętą i sakrament bierzmowania w kościele parafialnym w Rzewniu. Rodzinna parafia po zmianach organizacyjnych Kościoła w Polsce w 1992 r. została odłączona od diecezji płockiej i włączona do diecezji łomżyńskiej. Ireneusz po ukończeniu siedmiu klas odkrył w sobie pragnienie kapłaństwa i rozpoczął naukę w Liceum św. Stanisława Kostki w Płocku, które było jednocześnie Niższym Seminarium Duchownym diecezji płockiej. Religijna atmosfera domu rodzinnego, w którym wychowywał się Ireneusz, była wielokrotnie przedmiotem jego wspomnień. Szczególnie w swoim blogu w wielu miejscach wspominał zwyczaje panujące w jego domu ${ }^{2}$, rodziców ${ }^{3}$, dziadków ${ }^{4}$, klimat domu dzieciństwa i młodości ${ }^{5}$, swoją szkołę ${ }^{6}$ oraz kościół parafialny ${ }^{7}$.

Na decyzję o wyborze drogi kapłaństwa u młodego Mroczkowskiego mieli też wpływ duszpasterze z Rzewnia. Pierwszym z nich był ks. prała Stanisław Jakubiak, twórca parafii Rzewnie. O nim ks. Ireneusz w swoim blogu tak napisał: „Człowiek niewielkiego wzrostu, ale wielkiego ducha, doskonały organizator i mąż modlitwy. Potrafił z grupy ludzi, mieszkających cicho i spokojnie między Różanem i Pułtuskiem, stworzyć wspólnotę ducha i dobrze zorga-

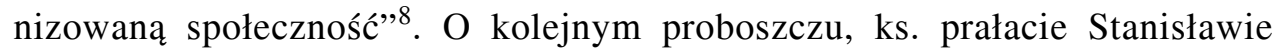
Welencu, ks. Ireneusz napisał: „Patrzyłem kątem oka na spokojną twarz Księdza Prałata, który w najlepszych swoich latach góry przenosił, spalając się w nauczaniu, budowaniu kościołów, uczeniu ludzi śpiewu, wystawianiu jasełek, pisaniu książek. Nie bał się komunistów, nie znosił kompromisów. Tak samo jak potrafił gromy rzucać z ambony, był też gotów do pójścia do więzienia za aresztowanego członka Solidarności"' ${ }^{\prime}$. Ks. Mroczkowski określił

\footnotetext{
${ }^{1}$ Ireneusz Mroczkowski, Szkoła w Rzewniu (31.08.2012), https://www.diecezjaplocka.pl/ blogi/ire neusz-mroczkowski/

${ }^{2}$ Por. Ojcowskie święcenie (10.04.2012).

${ }^{3}$ Por. Od Matki Bożej Brzemiennej do Matki Bożej Bolesnej (29.05.2012); Moje Soplicowo (14.07.2012); Aniot i niedzielne popołudnie (16.02.2014); Czarnobylska modlitwa (5.12.2015).

${ }^{4}$ Por. Panno święta, co Jasnej bronisz Częstochowy (8.06.2015).

${ }^{5}$ Por. Bociany (19.08.2012); Lyżeczka miodu (15.09.2012); Otwarta przestrzeń po zmartych (31.10.2013); Nikt nie woła? (9.08.2016); Jak przepowiadać w godzinie próby? (27.12.2018); Z mitości Zbawiciela. Moje ikony Jezusa (10.03.2019).

${ }^{6}$ Por. Szkoła w Rzewniu (31.08.2012).

${ }^{7}$ Por. Zapach Wiecznie Żyjacego (15.08.2014).

${ }^{8}$ Moi mistrzowie - kaptani (7.04.2012).

9 Tamże.
} 
duszpasterzy rodzinnej parafii takimi słowami: „Kapłaństwo moich proboszczów z Rzewnia było dobre jak chleb. Nigdy nie zapomnę podziwu parafian z tego powodu, że ich księża, chodząc po kolędzie, potrafili zostawić w biednych rodzinach to, co im ofiarowano w bogatszych"10.

Wzrastając w czasach komunistycznych w PRL młody chłopak z Gardziołek próbował łączyć zdobycze socjalne Polski Ludowej z wiarą religijną. O swoich poszukiwaniach napisał w blogu 23 marca 2017 r.: „Wiedzieli dobrze o tym marksistowscy propagandziści, którzy w latach mojej młodości wsączali w nasze młode umysły twierdzenie, że wiary nie da się połączyć z postępem. Ileż ja się wtedy namęczyłem; chciałem być tak samo postępowy, jak i wierzący. Jakim wybawieniem była każda wzmianka uczonego o tym, że jest wierzący. Skrupulatnie zbieraliśmy wszystkie dowody na istnienie Pana Boga, począwszy od Tomaszowych, poprzez te związane z objawieniami prywatnymi i egzystencjalnymi przeżyciami ludzi, przekonanych o interwencji Bożej w ich życiu"11.

Dla niego bycie postępowym oznaczało nade wszystko bycie otwartym na dialog oraz gotowość słuchania, nawet inaczej myślących. Głęboka i prawdziwa wiara dociekająca prawdy była połączona z żarliwym duchem apostolskim, gotowym podjąć dyskusję z innymi, by razem zmierzać ku odkryciu prawdy. Taka postawa charakteryzowała Profesora przez całe życie i jest jego niezwykłym charyzmatem. Tym, co ocalało spójność jego świata i pozwalało wierzyć, że wokół jest więcej dobra niż zła, była miłość rodzinna, którą romantycznie opisał w jednym blogu: „Stanął mi przed oczami przydrożny krzyż mojego dzieciństwa, przy którym w maju kwitły bzy, od którego wyglądało się, czy Mama nie wraca z Makowa, do którego wychodził Ojciec, by zobaczyć, czy synowie nie jadą na święta. Tam nauczyłem się wytrwale czekać i najmocniej tęsknić"12.

Ponieważ niższe seminarium jako szkoła kościelna nie miała praw organizowania egzaminu maturalnego, trzeba go było zdawać w innej szkole, w trybie eksternistycznym. Młody Mroczkowski zdał maturę w Liceum Ogólnokształcącym w Otwocku dopiero w 1968 r., gdy był już po pierwszym roku studiów seminaryjnych. W 1967 r. wstąpił do Wyższego Seminarium Duchownego diecezji płockiej. Podczas drugiego roku studiów seminaryjnych wraz z pięcioma swoimi kolegami z Płocka został wezwany do wojska i wcielony do jednostki wojskowej zorganizowanej specjalnie dla kleryków,

\footnotetext{
10 Tamże.

${ }^{11}$ Por. Z dobra wiara wobec watpiacych (29.03.2017).

${ }^{12}$ Krzyż w Porębie Żegoty (16.03.2012).
} 
by odwodzić ich od realizowania powołania. Na dworzec odprowadzano go w uroczystej procesji, w której szło prawie 100 kleryków płockiego seminarium na czele $\mathrm{z}$ rektorem, który był wzruszony do łez.

Dwa lata (1968-1970) spędzone w wojskowym reżimie w koszarach w 54 Batalionie Ratownictwa Terenowego w Bartoszycach, w tak zwanej jednostce kleryckiej, były próbą wiary i charakteru. Jednostka ta podlegała bezpośrednio Generalnemu Zarządowi Politycznemu Wojska Polskiego. Władze podejmowały wiele działań, by utrudniać alumnom praktyki religijne i tym samym zniechęcać do wiary i Kościoła. W okresie służby klerycy okazywali opór zamierzeniom władz, ale po powrocie do seminarium jedna czwarta z nich opuściła szeregi kandydatów do kapłaństwa. Po pomyślnym przejściu próby Ireneusz powrócił do studiów teologii. Charakteryzując czas formacji seminaryjnej, już jako rektor płockiego seminarium, napisał: „Oprócz kontemplacji, potrzebna jest sprawność umysłu. Trzeba ten świat rozumieć, poznawać jego dumne i wspaniałe osiągnięcia, umieć je ocenić i wykorzystać dla rozwoju duchowego człowieka, któremu przecież każdy ksiądz służy w szkole, na ambonie, w konfesjonale, przy łóżku w szpitalu. Wszędzie potrzebna jest psychologia, socjologia, elementy wiedzy medycznej i wielu innych nauk o człowieku"13.

Podczas III roku kleryk Ireneusz przyjął strój duchowny, a następnie otrzymał posługi lektora i akolity. $\mathrm{W}$ trakcie $\mathrm{V}$ roku seminarium, dnia 4 marca 1973 r. został wyświęcony na diakona przez bpa Bogdana Sikorskiego. Pracę dyplomowa na temat: Wolność woli w marksizmie i tomizmie napisał pod kierunkiem wicerektora seminarium ks. Tadeusza Rutowskiego ${ }^{14}$. Święceń kapłańskich w Makowie Mazowieckim udzielił Mroczkowskiemu 16 czerwca 1974 r. Biskup Płocki Bogdan Sikorski. Prymicje miały miejsce w rodzinnej parafii Rzewnie w następną niedzielę - 23 czerwca.

\section{PIERWSZE LATA KAPŁAŃSTWA}

Pierwszą placówką duszpasterską neoprezbitera była parafia pod wezwaniem Świętej Trójcy w Rypinie, gdzie uczył się posługi duszpasterskiej od proboszcza ks. prałata Czesława Chojeckiego ${ }^{15}$. Po dwóch latach ks. Ire-

\footnotetext{
13 Ireneusz Mroczkowski, Wdzięczność i nadzieja. Przemówienia rektorskie 1999-2005 (Płock: Płocki Instytut Wydawniczy, 2007), 20.

${ }^{14}$ Por. Ireneusz Mroczkowski, Dziękuje Ci Księże Rektorze (20.02.2018).

15 Por. Michał Marian Grzybowski, Ksiadz prałat Czesław Chojecki proboszcz i dziekan w Rypinie (Płock: Płocki Instytut Wydawniczy, 2005), 39.
} 
neusz został przeniesiony do parafii św. Michała w Płońsku, gdzie pracował rok, pod kierunkiem proboszcza ks. kanonika Stanisława Kowalczyka. Młody wikary odznaczał się zapałem duszpasterskim w prowadzeniu katechezy, organizowaniu grup młodzieży gromadzącej się przy kościele oraz zainicjowaniu powstania scholii młodzieżowej.

W 1977 r. ks. Mroczkowski został skierowany na studia magistersko-licencjackie na Katolickim Uniwersytecie Lubelskim w Lublinie w zakresie teologii moralnej. Jego profesorami byli księża: Władysław Poplatek, Stanisław Witek, Seweryn Rosik oraz Franciszek Greniuk. Dnia 26 czerwca 1979 r. obronił pracę magisterską pod tytułem Problematyka moralna $w$ dziełach Stanisława Przybyszewskiego, napisana pod kierunkiem ks. prof. Stanisława Witka $^{16}$. Recenzentem był ks. prof. Seweryn Rosik. Po trzecim roku studiów, w czerwcu 1980 r., zdał egzamin licencjacki uprawniający go do nauczania teologii w instytucjach kościelnych.

W 1980 r. ks. Mroczkowski podjął studia z teologii moralnej na Akademii Alfonsjańskiej w Rzymie, będącej częścią Papieskiego Uniwersytetu Laterańskiego. Okres czterech lat spędzonych w stolicy chrześcijaństwa otworzył go na uniwersalizm powołania chrześcijańskiego. Początek pontyfikatu św. Jana Pawła II był czasem krystalizowania się posoborowej teologii moralnej, która wkraczała na nowe tory wyznaczane przez profesorów rzymskich uczelni, do których należeli: Bernard Häring, Klaus Demmer i Domenico Capone. Ks. Mroczkowski napisał pracę doktorską pod kierunkiem o. prof. Jullio de La Torre i obronił ją 18 maja 1984 r. Tytuł pracy brzmiał: La dimensione etico-teologica dei diritti dell'uomo. 25 czerwca 1985 r. dysertacja została nostryfikowana na KUL-u.

Pierwsze lata po powrocie z Rzymu ks. Ireneusz spędził w Płocka, gdzie objął funkcję ojca duchownego alumnów Wyższego Seminarium Duchownego. Obok głoszenia konferencji, prowadzenia spotkań formacyjnych, młody teolog włączył się w animowanie kleryków do działań kulturalnych, społecznych i charytatywnych. Opiekował się seminaryjnym Kołem Miłosierdzia organizującym akcje charytatywne wraz z siostrami Matki Teresy z Kalkuty ${ }^{17}$. Mroczkowski prowadził w seminarium wykłady z zakresu teologii moralnej, katolickiej nauki społecznej oraz etyki. Rozpoczął też wykład spowiednictwa. Jego zapał duszpasterski i rzutkość organizacyjna kazały mu się włączyć w dialog społeczny, do którego wdrażał kleryków.

\footnotetext{
${ }^{16}$ Por. Franciszek Greniuk, „Kronika Sekcji Teologii Moralnej KUL za rok 1978-1979”, Roczniki Teologiczno-Kanoniczne 27, z. 3(1980): 98.

${ }^{17}$ Por. Ireneusz Mroczkowski, Działalność organizacyjna i wychowawcza, Archiwum KUL, s. 2.
} 


\section{PRACA NAUKOWA NA KUL-u}

Od października 1985 r. ks. Mroczkowski podjął pracę na KUL-u jako asystent w Sekcji Teologii Moralnej, dojeżdżając do Lublina z Płocka. Na pewnym etapie, chcąc się bardziej związać ze środowiskiem kulowskim, zakupił mieszkanie w Lublinie. Powierzono mu zajęcia monograficzne dla doktorantów oraz wykłady kursoryczne dla studentów świeckich. W swoich badaniach, którymi dzieli się ze studentami, podejmował zagadnienia praw człowieka, prawa naturalnego oraz sakramentologii. Istotnym tematem, który stał się przedmiotem jego przyszłej habilitacji, była teologicznomoralna wizja cielesności. Po dwóch latach zatrudnienia na KUL-u, od 1 października 1987 r. ks. Ireneusz został starszym asystentem. Od 1 października 1990 r. został awansowany na stanowisko adiunkta. Po uzyskaniu habilitacji od 1 czerwca 1998 r. objął stanowisko profesora nadzwyczajnego. W latach 1997-2002 pełnił funkcję kierownika Katedry Teologii Moralnej Ogólnej ${ }^{18}$.

Na początku roku 1994 ks. Mroczkowski złożył dokumenty do wszczęcia przewodu habilitacyjnego. Podstawą ubiegania się o stopień naukowy było kilkadziesiąt artykułów oraz książka Osoba i cielesność. Moralne aspekty teologii ciata ${ }^{19}$. Recenzentami dorobku naukowego zostali wybitni profesorowie teologii moralnej w Polsce: ks. prof. dr hab. Helmut Juros, ks. prof. dr hab. Paweł Góralczyk oraz ks. prof. dr hab. Janusz Nagórny. Prof. Juros napisał w recenzji, że ,wzięcie udziału w przewodzie habilitacyjnym ks. dr. Ireneusza Mroczkowskiego obiecuje recenzentowi satysfakcję naukową, iż będzie uczestniczył w akcie kreowania nowego samodzielnego pracownika nauki”20. Podkreślił on walory poznawcze, merytoryczne i metodologiczne twórczości naukowej Mroczkowskiego oraz wskazał na szlachetne przymioty osobowościowe i talent organizacyjny, które potwierdzają słuszność starań o uzyskanie awansu naukowego.

Ks. prof. Góralczyk docenił u ks. Mroczkowskiego solidność naukową w prowadzeniu badań oraz liczące się wyniki publikacji w zakresie metodologii teologii moralnej. Recenzent stwierdził, że habilitant ma doskonały warsztat naukowy oraz odwagę w stawianiu pytań w zakresie istotnych problemów na styku filozo-

\footnotetext{
18 Por. Adam Zadroga, ,Teologia moralna na Katolickim Uniwersytecie Lubelskim Jana Pawła II", w Polska teologia moralna czterdzieści lat po Soborze Watykańskim II, red. Janusz Nagórny, Jerzy Gocko (Lublin: Gaudium, 2006), 202.

${ }^{19}$ Płock 1994.

${ }^{20}$ Por. Helmut Juros, Recenzja rozprawy habilitacyjnej ks. dr. Ireneusza Mroczkowskiego, Archiwum KUL, s. 1.
} 
fii i teologii ${ }^{21}$. Ks. prof. Nagórny w swojej recenzji podkreślił „ogromne otwarcie się Autora na wyzwania współczesności i śmiałe podjęcie dialogu z wieloma prądami myślowymi obecnego czasu oraz poszukiwanie we współczesnych dokonaniach nauk o człowieku tego wszystkiego, co pomogłoby stałą i niezmienna w swej istocie moralną doktrynę Kościoła przybliżyć człowiekowi dzisiejszemu" ${ }^{\text {"2 }}$. Kolokwium habilitacyjne w dniu 6 czerwca 1994 r. miało pozytywny przebieg i zakończyło się odpowiednią uchwałą Rady Wydziału Teologii. Centralna Komisja ds. Stopni i Tytułów Naukowych 24 października 1994 r. zatwierdziła nadanie ks. Mroczkowskiemu stopnia doktora habilitowanego.

Prowadząc wykłady i seminaria naukowe ks. Ireneusz wypromował na KUL-u 29 magistrów i trzech doktorów. Napisał 5 recenzji doktoratów bronionych na KUL-u. Od końca lat 90. został zatrudniony w Warszawie na Akademii Teologii Katolickiej, do której było włączone seminarium diecezjalne w Płocku. Zamieszkał w Płocku i przyjeżdżał do Lublina na zajęcia ze studentami.

Starania o uzyskanie tytułu profesora nauk teologicznych podjął na KUL-u w listopadzie roku 2000. W autoreferacie ks. Mroczkowski wskazał pięć zagadnień będących przedmiotem jego badań naukowych: metodologię teologii moralnej; chrześcijańską moralność społeczną i rozumienie praw człowieka; powołanie i posłannictwo świeckich we współczesnym Kościele; historyczne i współczesne rozumienie cielesności człowieka oraz problematykę zła i grzechu ${ }^{23}$. Podkreślił też, że istotnym zagadnieniem rozwijanym $w$ jego twórczości naukowej jest antropologia teologicznomoralna. W ramach dorobku naukowego po uzyskaniu habilitacji ks. Mroczkowski opublikował 70 artykułów naukowych i 3 monografie. Wypromował jednego doktora i prowadził sześć rozpoczętych przewodów doktorskich ${ }^{24}$. Był promotorem 58 magisteriów i ponad 50 prac dyplomowych.

Jako efekt swej pracy naukowej wskazał udział w licznych sympozjach i konferencjach naukowych, podczas których wygłaszał referaty. W ramach Sekcji Teologii Moralnej na KUL-u w latach 1990-2002 współorganizował

\footnotetext{
${ }^{21}$ Por. Paweł Góralczyk, Recenzja dorobku naukowego ks. dr. Ireneusza Mroczkowskiego, Archiwum KUL, s. 24.

${ }^{22}$ Por. Janusz Nagórny, Ocena rozprawy habilitacyjnej i dorobku naukowego ks. dr. Ireneusza Mroczkowskiego, Archiwum KUL, s. 2.

${ }^{23}$ Por. Ireneusz Mroczkowski, Autoreferat o zainteresowaniach, osiagnięciach $w$ dziatalności naukowo-badawczej oraz w ksztattowaniu kadr naukowych. Lublin 28.11.2000, Archiwum KUL, s. 1.

${ }^{24}$ Por. Marek Niedźwiecki, Odnowa i rozwój polskiej teologii moralnej po Soborze Watykańskim II (Kraków: Wydawnictwo UNUM, 2002), 198.
} 
coroczne sympozja, na których dzielił się swymi badaniami naukowymi. Od roku 1995 włączył się w działania ogólnopolskiej sekcji teologów moralistów i czynnie uczestniczył we wszystkich dorocznych spotkaniach naukowych. Zapraszano go jako prelegenta na spotkania psychologów, lekarzy oraz rektorów wyższych seminariów duchownych w Polsce.

Recenzentami w przewodzie o nadanie tytułu profesora byli: ks. prof. Alojzy Marcol z Opola, ks. prof. Paweł Góralczyk z Warszawy i ks. prof. Janusz Nagórny z Lublina. Wszyscy trzej napisali bardzo pozytywne recenzje, wskazując na znaczące walory dorobku naukowego ks. Ireneusza i doceniając jego postawę jako aktywnego uczestnika życia naukowego w Polsce. Ks. Marcol stwierdził: „Z przeglądu działalności naukowo-badawczej, dydaktycznej i organizacyjnej ks. dr. hab. Ireneusza Mroczkowskiego, profesora KUL, wyłania się sylwetka człowieka głęboko zaangażowanego i oddanego etyce i teologii moralnej. Lektura pokaźnego dorobku Autora wymaga szczególnego uznania dla wartości treściowej i formalnej" 25 .

Ks. prof. Góralczyk podkreślił, że ,piśmienniczy dorobek naukowy ks. dr hab. Ireneusza Mroczkowskiego po habilitacji jest w swojej treści znaczący, wskazuje na trwałe zaangażowanie się w pracy naukowej, której wyniki ubogacają polską teologię moralną, a osobę ks. Mroczkowskiego wysuwają do czołówki teologów w Polsce" ${ }^{26}$. W recenzji ks. Nagórnego znalazło się stwierdzenie, że ks. Mroczkowski wniósł wielki wkład do środowiska lubelskiego w postaci dociekliwości badawczej, dopracowanych warsztatowo publikacji oraz interesującej i bogatej w treści problematyki wykładów i pisanych tekstów. Recenzent podkreślił odwagę kandydata na profesora w podejmowaniu refleksji nad trudnymi zagadnieniami teologicznomoralnymi, które wymagają dyscypliny umysłu i wrażliwości ser$\mathrm{ca}^{27}$. Rada Wydziału KUL 26 czerwca 2001 r. podjęła uchwałę o nadaniu tytułu profesora teologii ks. Mroczkowskiemu.

\footnotetext{
${ }^{25}$ Alojzy Marcol, Ocena całokształtu dorobku naukowego ks. dr hab. Ireneusza Mroczkowskiego, Archiwum KUL, s. 7.

${ }^{26}$ Paweł Góralczyk, Ocena całokształtu dorobku naukowego ks. dr hab. Ireneusza Mroczkowskiego, Archiwum KUL, s. 11.

${ }^{27}$ Por. Janusz Nagórny, Recenzja dorobku naukowego i osiagnięć dydaktycznych ks. $d r$. hab. Ireneusza Mroczkowskiego, Archiwum KUL, s. 1-10.
} 


\section{DYDAKTYKA NA INNYCH UCZELNIACH}

W ciagu wielu lat swojej aktywności naukowej ks. Ireneusz podejmował zajęcia dydaktyczne w innych uczelniach. Od roku 1984 prowadził wykłady kursoryczne w Filii ATK w Płocku, która w 1999 r. została przemianowana na filię UKSW. W latach 1995-2000 wykładał etykę ogólną w Szkole Wyższej im. Pawła Włodkowica w Płocku. Dzięki swej otwartości na współpracę ze świeckimi oraz gotowość wsłuchiwania się w sprawy spotykanych osób, szybko zyskał sobie autorytet zaangażowanego nauczyciela akademickiego, który nie tylko przekazywał mądre treści wykładów, ale też dzielił się przeżywanymi przez siebie wartościami zaczerpniętymi ze skarbca Ewangelii.

W latach 1999-2005 dojeżdżał z wykładami do Akademii Humanistycznej im. Aleksandra Gieysztora w Pułtusku. Szkoła ta, nazywająca się wcześniej Wyższa Szkoła Humanistyczna, powstała w 1994 r. z inicjatywy Akademickiego Towarzystwa Edukacyjno-Naukowego ATENA. Ks. Mroczkowski wykładał w niej etykę, wskazując na najistotniejsze zasady postępowania człowieka w aspekcie dobra i zła. Jak zawsze, jego wykłady miały duży rezonans społeczny, gdyż były przekazywane w żywej formie nawiązującej aktywny kontakt ze słuchaczami.

Po zakończeniu w 2002 r. pracy naukowo-dydaktycznej na KUL-u od 1 października b.r. ks. Ireneusz został zatrudniony na stanowisku profesora nadzwyczajnego na USKW w Warszawie na Wydziale Teologicznym. Trzy lata później, 1 lipca 2005 r. został zatrudniony na stanowisku profesora zwyczajnego. Od 2010 r. został przeniesiony do Katedry Antropologii i Bioetyki na Wydziale Nauk o Rodzinie, który miał wówczas siedzibę w Łomiankach. W trakcie pracy na tym wydziale samorząd studencki UKSW w roku 2016 wyróżnił go statuetką Belfer Roku, przyznawaną nauczycielom akademickim, którzy zdaniem studentów najlepiej wypełniaja swoje zadania.

Ireneusz Mroczkowski pracował na UKSW do 30 września 2018 r., po czym podjął wykłady w Państwowej Uczelni Zawodowej im. Ignacego Mościckiego w Ciechanowie na Wydziale Ochrony Zdrowia i Nauk Humanistycznych na kierunku pielęgniarstwo i kulturoznawstwo, gdzie był zatrudniony do śmierci. Ks. Mroczkowski wykładał w Ciechanowie etykę, ucząc swoich studentów rozstrzygania dylematów moralnych oraz ukazując piękno chrześcijańskiej moralności. W wypowiedziach na temat swojej pracy dydaktycznej kierowanych do kolegów ze Stowarzyszenia Teologów Moralistów wyrażał radość i poczucie odpowiedzialności za kształtowanie sumień młodych ludzi podejmujących różne role społeczne. 


\section{POSŁUGA W KOŚCIELE LOKALNYM W PŁOCKU}

Już w czasie pracy na KUL-u ks. Ireneusz zajmował się organizowaniem tygodni kultury chrześcijańskich w różnych miastach Polski, wygłaszając na nich odczyty i konferencje. Ponadto w ramach Klubu Inteligencji Katolickiej w Płocku również wygłaszał odczyty na tematy z zakresu teologii moralnej. Gościł też regularnie na falach Radia Płock, gdzie głosił półgodzinne wykłady ${ }^{28}$.

W ramach posługi w diecezji płockiej ks. Mroczkowski pełnił różne funkcje, które wyrażają jego ogromne zaangażowanie naukowe i duszpasterskie oraz potwierdzają jego umiłowanie Kościoła i poczucie odpowiedzialności za przekaz wiary oraz rozwijanie kultury chrześcijańskiej. Obok wykładów prowadzonych w seminarium płockim był też rektorem tej placówki w latach 1999-2005. Zapisał się jako kapłan oddany wychowankom i potrafiący nawiązać dialog z innymi wychowawcami. Zaktywizował środowisko seminaryjne i współorganizował cykliczne sympozja naukowe odważnie podejmujące aktualne problemy Kościoła w Polsce ${ }^{29}$.

W latach 1987-1999 był asystentem Klubu Inteligencji Katolickiej w Płocku, organizując spotkania naukowe i dyskusyjne oraz prowadząc duszpasterstwo ludzi świeckich. Kierując się wytycznymi adhortacji apostolskiej Jana Pawła II Christifideles laici, ks. Mroczkowski organizował formację świeckich katolików, ucząc ich współdziałania w życiu społecznym i rozwijania poczucia odpowiedzialności za Polskę ${ }^{30}$. Ważnym miejscem współpracy ze świeckimi były też komisje synodalne, w których czynny udział brał ks. Profesor.

Innym polem działalności społecznej i duszpasterskiej była posługa w ramach Towarzystwa Naukowego Płockiego. Powstało ono w 1820 r. i działa na podstawie społecznego zaangażowania wielu znakomitych osobistości regionu. Ks. Mroczkowski czynnie włączył się w prace Towarzystwa i w 2013 r. przyczynił się do powstania Sekcji Dialogu między Nauką, Wiarą i Kulturą. W ramach powyższej sekcji organizował interdyscyplinarne seminaria naukowe gromadzące przedstawicieli różnych religii i dyscyplin naukowych. Dużą popularno-

${ }^{28}$ Por. Mroczkowski, Działalność organizacyjna $i$ wychowawcza, 3-5.

29 Por. Wojciech Góralski, „Kompetentnie, z oddaniem i wytrwałością. Ks. Ireneusz Mroczkowski jako rektor Wyższego Seminarium Duchownego w Płocku (1999-2005)", w Dyscyplina rozumu i uczciwość serca. Ks. Ireneusza Mroczkowskiego (1949-2020) sposób uprawiania teologii moralnej, red. Andrzej Derdziuk, Wojciech Kućko (Lublin: Towarzystwo Naukowe KUL, 2020), 67-81.

${ }^{30}$ Por. Remigiusz Stacherski, ,Rola katolików świeckich w odnowie Kościoła płockiego w publikacjach i działalności ks. Ireneusza Mroczkowskiego", w Dyscyplina rozumu i uczciwość serca, 89-92. 
ścią cieszyły się też organizowane przez ks. Ireneusza comiesięczne spotkania w cyklu „Ludzie dialogu w Płocku po 1989 roku”. Gromadziły one osoby z różnych środowisk i budowały kulturę dialogu i współpracy ${ }^{31}$.

W latach 1997-2012 ks. Mroczkowski był redaktorem naczelnym „Studiów Płockich”, które dzięki niemu zyskały większy prestiż naukowy oraz otwarły się na szerszą perspektywę badawczą i popularyzatorską. Inicjował on szeroką dyskusję naukową na temat wyzwań duszpasterskich i kulturowych Kościoła w Polsce oraz zapraszał wybitnych autorów do publikowania w czasopiśmie. Sam też publikował swoje artykuły w prowadzonym przez siebie periodyku i obok słowa wstępnego pisał teksty podejmujące aktualne zagadnienia teologiczne. Za czasów jego redaktorstwa ukazało się szesnaście tomów „Studiów Płockich" ${ }^{, 32}$.

W latach 1997-2011 prof. Mroczkowski był członkiem Komisji do spraw Dialogu między Kościołem Rzymskokatolickim i Kościołem Starokatolickim Mariawitów, biorąc udział w spotkaniach roboczych i wypracowując stanowisko w kwestiach teologicznych i duszpasterskich. W latach 2008-2018 był opiekunem wspólnoty Wdów Konsekrowanych w diecezji płockiej, prowadząc dla nich rekolekcje i dni skupienia, organizując życie religijne wspólnoty oraz dbając o przygotowanie uroczystości poświęcenia się służbie Bogu i Kościołowi ${ }^{33}$.

Należy też wspomnieć bardzo ofiarne zaangażowanie ks. profesora Mroczkowskiego w działalność Sekcji Polskich Teologów Moralistów, a od 2006 r. Stowarzyszenia Teologów Moralistów w Polsce. Ks. Ireneusz był pierwszym przewodniczącym zarejestrowanego jako organizacja pożytku publicznego stowarzyszenia moralistów a także jego nieocenionym animatorem w zakresie dorocznych spotkań, działalności naukowej oraz integrowania środowiska teologów moralistów w Polsce. Jego entuzjazm porywał wielu członków stowarzyszenia, a jego ciekawość w zadawaniu pytań i radość wyrażana z osiągnięć młodszych kolegów i koleżanek była czynnikiem inspirującym teologów moralistów w Polsce.

Doświadczenie pracy z nim w ramach Sekcji Teologii Moralnej KUL oraz Stowarzyszenia Teologów Moralistów w Polsce ukazywało jego przyjazne nastawienie do młodszych kolegów i koleżanek oraz szacunek dla nestorów

\footnotetext{
31 Por. Daniel Brzeziński, „Działalność ks. Ireneusza Mroczkowskiego w Towarzystwie Naukowym Płockim”, w Dyscyplina rozumu i uczciwość serca, 94-103.

32 Por. Mirosław Kosek, „W trosce o Kościół partykularny. Ks. Ireneusz Mroczkowski jako redaktor naczelny «Studiów Płockich»”, w Dyscyplina rozumu i uczciwość serca, 105-15.

${ }^{33}$ Por. Andrzej Derdziuk, ,Życiorys naukowy ks. Ireneusza Mroczkowskiego”, w Dyscyplina rozumu i uczciwość serca, 32.
} 
teologii. Przewodnicząc Stowarzyszeniu Teologów Moralistów przez kilka kadencji, potrafił odkrywać młode talenty i dowartościował dokonania starszych kolegów. Otwierał doroczne spotkania naukowe na prelegentów z zewnątrz, pragnąc usilnie nawiązać dialog ze światem współczesnym, w tym $\mathrm{z}$ osobami niewierzącymi, które prezentowały odmienny punkt widzenia. Swoją radością i życzliwością łączonymi z prostotą inicjował burzliwe dyskusje i zachęcał do wypowiadania krytycznych uwag. Symptomatyczne było zgłaszanie się ks. Mroczkowskiego do mównicy podczas dorocznych sesji z dociekliwymi pytaniami, które nie tylko wskazywały na jego pragnienie rozjaśnienia pojawiających się wątpliwości, lecz także otwierały uszy słuchaczy na konieczność jasnego i precyzyjnego uzasadniania głoszonych prawd moralnych.

\section{GŁÓWNE ZAKRESY BADAŃ NAUKOWYCH}

KS. MROCZKOWSKIEGO

W dorobku naukowym i publicystycznym ks. prof. Ireneusza Mroczkowskiego znajduje się ponad 280 publikacji, w tym 14 książek, wiele artykułów naukowych, haseł encyklopedycznych i słownikowych oraz recenzji i sprawozdań naukowych ${ }^{34}$. Wśród książek warto zauważyć trzy zbiory jego felietonów zamieszczanych wcześniej na blogu, który ks. Ireneusz prowadził z niestrudzonym zapałem, komentując wiele aktualnych wydarzeń i dzieląc się swoimi przemyśleniami na temat moralnego aspektu obserwowanych zjawisk. Posługa myślenia, którą dzielił się Profesor z Płocka, była skierowana do prostych odbiorców i miała swój szeroki zasięg. Jego blog był systematycznie uzupełniany, a zawarte $\mathrm{w}$ nim przemyślenia poruszały ważne kwestie dotyczące kondycji moralnej współczesnego człowieka ${ }^{35}$.

Ksiądz Mroczkowski był promotorem czterech rozpraw doktorskich i 153 prac magisterskich. Przygotował dwie recenzje dorobku naukowego w związku z nadaniem doktoratu honoris causa. Był ponadto recenzentem w ramach ubiegania się czterech osób do nominacji profesorskich i oceniał dorobek naukowy siedmiu osób starających się o uzyskanie stopnia doktora habilitowanego. Proszono go

\footnotetext{
${ }^{34}$ Por. Anna Janiszewska i Wojciech Kucko, „Bibliografia prac ks. Ireneusza Mroczkowskiego", w Dyscyplina rozumu i uczciwość serca, 35-52.

35 Por. Tadeusz Zadykowicz, „Ks. Ireneusz Mroczkowski - Autor bloga”, w Dyscyplina rozumu i uczciwość serca, 117-45.
} 
o sporządzenie dwudziestu recenzji prac doktorskich ${ }^{36}$. Jego oceny dorobku naukowego były krytyczne i dogłębnie analizujące badane zagadnienie. Zarazem było w nich wiele ludzkiej życzliwości, która nie przemilczając słabych stron, potrafiła znajdować pozytywne aspekty ocenianych rozpraw.

Wśród kwestii podejmowanych w badaniach naukowych prof. Mroczkowskiego trzeba wskazać na metodologię uprawiania nauki, antropologię teologicznomoralną, teologię ciała, małżeństwo i rodzinę, feminizm, prawa człowieka, moralność życia społeczno-politycznego oraz ekologię. Zabierał też głos w sprawach wychowania seminaryjnego, kondycji Kościoła w Polsce, powołania i posłannictwa świeckich we współczesnym Kościele oraz aktualnego stanu świadomości moralnej.

$\mathrm{Z}$ właściwą sobie pasją i umiłowaniem tematu ks. Ireneusz zajmował się refleksją nad naukowym statusem teologii moralnej. Temu zagadnieniu służyły inicjatywy zmierzające do powstania podręcznika teologii moralnej oraz wypowiedzi w postaci artykułów i książek poświęconych tej kwestii ${ }^{37}$. Potwierdzeniem tego jest książeczka Teologia moralna. Definicja. Przedmiot. Metoda $^{38}$, obejmująca cztery rozdziały omawiające definicję, przedmiot oraz źródła i metodę teologii moralnej. Autor wskazuje na potrzebę włączenia się teologii moralnej w krytyczny dialog między wiarą a praktycznym rozumem posługującym się etyką.

Zagadnienie antropologii teologicznomoralnej zajmowało ks. Ireneusza od dawna i przyczyniło się do powstania ważnych publikacji, które ukazują dociekliwość badawczą i głębię myślenia nieunikającą trudnych pytań i wskazująca teologiczną perspektywę spojrzenia na człowieka. Wśród prac z tego zakresu trzeba koniecznie wspomnieć książkę Natura osoby ludzkiej. Podstawy tożsamości człowieka $^{39}$. Publikacja ta ma na celu ukazanie podstaw filozoficznej i teologicznej refleksji o człowieku. Istnienie poprzedzające działanie zanalizowano w świetle różnych nauk, a także została podjęta próba syntezy osiagnięć nauk przyrodniczych i społecznych w świetle antropologii filozoficzno-teologicznej. Refleksja Profesora wypływa z egzystencjalnego doświadczenia człowieka jako bytu moralnego otwartego na dobro. Potwierdzeniem tego jest dedykacja książki, którą

\footnotetext{
${ }^{36}$ Por. Anna Janiszewska i Wojciech Kućko, „Ks. Ireneusz Mroczkowski - promotor prac magisterskich i doktorskich, recenzent w przewodach doktorskich, habilitacyjnych i profesorskich”, w Dyscyplina rozumu i uczciwość serca, 53-66.

${ }^{37}$ Por. Andrzej Derdziuk, ,Inicjator opracowywania podręcznika teologii moralnej”, w $D y$ scyplina rozumu i uczciwość serca, 149-62.

38 (Płock: Płocki Instytut Wydawniczy, 2011).

39 (Płock: Płocki Instytut Wydawniczy, 2012).
} 
poświęcił swoim rodzicom - Weronice i Edwardowi. Tajemnicę człowieka ks. Mroczkowski rozważał też w publikacji Chrześcijańska tożsamość osoby. Zarys antropologii moralnoteologicznej ${ }^{40}$. Przyjmując ideę transcendencji podmiotu zmierzał do wypracowania antropologii adekwatnej, która jest w stanie zmierzyć się z wyzwaniami współczesnej kultury.

Rozważania na temat teologii ciała były przedmiotem wykładu monograficznego na KUL-u oraz książki habilitacyjnej. Wydana po raz pierwszy w Płocku w 1994 r. publikacja została potem wznowiona w roku 2008. Inspiracją do zajęcia się tym tematem był cykl katechez św. Jana Pawła II poświęconych tematowi małżeństwa i rodziny. W tym czasie ks. Ireneusz odbywał studia specjalistyczne w Rzymie i mógł być świadkiem tych wydarzeń. Prezentując metodologię swego podejścia do tematu ks. Mroczkowski napisał: „Nie będziemy budować antropologii filozoficznej, która uogólnia i syntetyzuje humanistyczne i biologiczne dane o człowieku. $\mathrm{Z}$ drugiej jednak strony, opierając się zasadniczo na antropologii kard. Wojtyły, budowanej w Osobie i czynie, będziemy uwzględniać właśnie uwarunkowania natury biologicznej i psychologicznej. Będziemy się starać wiernie opisać doświadczenie człowieka, które wskazuje na realność istnienia osoby, różnorodność dynamizmów cielesno-psychologicznych oraz znaczenie mowy ciała" ${ }^{41}$. Oparcie refleksji namysłu teologa wsłuchującego się w ludzką egzystencję na biblijnym fundamencie zaowocowało tym, że ,udało się wydobyć nowe i aktualne znaczenie cielesności, ubogacając je licznymi odniesieniami do współczesnej dyskusji antropologicznej, filozoficznej i teologicznej”,42.

Tematyką integralnie związaną z papieską teologią ciała była troska o właściwe rozumienie misji małżeństwa i rodziny oraz sposób ujmowania posłannictwa kobiety. Ks. Mroczkowski nie tylko publikował w tym zakresie książki, artykuły i przemyślenia na blogu, ale też inicjował działania duszpasterskie, w których sam aktywnie uczestniczył. Owocem jego poszukiwań naukowych są pozycje: Etos mitosierdzia a wierność matżeńska. Moralne dylematy osób żyjacych $w$ zwiazkach niesakramentalnych $w$ świetle adhortacji „Amoris laetitia” papieża Franciszka ${ }^{43}$ oraz Rodzina, gender i ,nowy” feminizm. Podstawy chrze-

\footnotetext{
40 (Płock: Płocki Instytut Wydawniczy, 2016).

41 Ireneusz Mroczkowski, Osoba i cielesność. Moralne aspekty teologii ciała (Płock: Płocki Instytut Wydawniczy, 1994), 14.

${ }^{42}$ Wojciech Kućko, „Interpretacja teologii ciała św. Jana Pawła II w twórczości ks. Ireneusza Mroczkowskiego", w Dyscyplina rozumu i uczciwość serca, 206.

43 (Płock: Płocki Instytut Wydawniczy, 2017).
} 
ścijańskiej obrony i promocji rodziny ${ }^{44}$. Profesor zaproponował wielką dziewięcioletnią nowennę narodową w obronie rodziny, by promować wartości spajające wspólnoty rodzinne i będące podstawą nowego ładu społecznego ${ }^{45}$.

Zwracając uwagę na nasilające się ataki na chrześcijańską wizję rodziny, Moralista z Połocka rozwijał koncepcję nowego feminizmu w ujęciu Jana Pawła $\mathrm{II}^{46}$ oraz przeciwstawiał się ideologii gender ${ }^{47}$. Opisując jego wkład w kwestię obrony rodziny Agata Rujner napisała: „można potwierdzić nie tylko szczególne ukierunkowanie ks. Mroczkowskiego na rodzinę, ale również sformułować tezę, że wychował on niejedno pokolenie ludzi świeckich (i nie tylko), odkrywając głębię teologii ciała, teologii małżeństwa i rodziny, a dzięki kontaktom ze studentami mógł nieustannie weryfikować głoszoną przez siebie teologię i pogłębiać argumentację"48.

W zakresie problematyki społecznej interesowały Profesora zarówno kwestia praw człowieka ${ }^{49}$, jak i szerzej pojętej moralności życia gospodarczego $^{50}$. Obok prowadzonych wykładów monograficznych pozostawił po sobie kilka artykułów na ten temat oraz wiele wypowiedzi na sympozjach i konferencjach naukowych. Współpracował też ze środowiskiem biznesowym i udzielał się w duszpasterstwie ludzi pracy. Przez pewien czas w swojej twórczości zajmował się też kwestią zła i grzechu, bo to było przedmiotem jego monografii profesorskiej ${ }^{51}$ oraz kilku artykułów $\mathrm{z}$ tego zakresu $^{52}$.

44 (Płock: Płocki Instytut Wydawniczy, 2014).

${ }^{45}$ Por. Ireneusz Mroczkowski, „Nowa Wielka Nowenna? Zarys programu obrony rodziny w Polsce”, Teologia i Moralność 4(2008): 183-192.

${ }^{46}$ Por. Ireneusz Mroczkowski, „«Nowy feminizm» w nauczaniu Jana Pawła II”, Roczniki Teologiczne 10(2006): 213-24.

47 Por. Marian Machinek, „Teologia moralna wobec genderyzmu. Refleksja na kanwie publikacji ks. Ireneusza Mroczkowskiego", w Dyscyplina rozumu i uczciwość serca, 211-24.

48 Agata Rujner, „Małżeństwo i rodzina w perspektywie nadziei”, w Dyscyplina rozumu i uczciwość serca, 313

49 Por. Jerzy Gocko, „O etyczny i teologiczny wymiar praw człowieka. Rozważania na kanwie badań ks. Ireneusza Mroczkowskiego nad prawami człowieka”, w Dyscyplina rozumu i uczciwość serca, 163-77.

${ }^{50}$ Por. Adam Zadroga, ,Moralne aspekty przedsiębiorczości, bogactwa i kariery w ujęciu ks. Ireneusza Mroczkowskiego”, w Dyscyplina rozumu i uczciwość serca, 257-67.

${ }^{51}$ Por. Ireneusz Mroczkowski, Zto i grzech. Studium filozoficzno-teologiczne (Lublin: RW KUL, 2000).

52 Ireneusz Mroczkowski, „Zło w ujęciu P. Ricoeura”, Roczniki Teologiczne 47, z. 3 (2000): 31-45; „Zło radykalne w ujęciu I. Kanta”, Studia Płockie 25(1997): 99-107. 
Kwestii ekologii ks. Mroczkowski poświęcił kilka tekstów publikowanych w pracach zbiorowych ${ }^{53}$.

Opisując koleje życia i dokonania naukowe oraz organizacyjne Profesora z Płocka, należy nade wszystko pamiętać, że ks. Ireneusz był dobrym, radosnym i życzliwym człowiekiem, który nawet znosząc poważną chorobę, nie zatrzymał się na swoich sprawach, ale zawsze był otwarty na Boga i drugiego człowieka. Jego prosta wiara, współdziałająca z dociekliwym rozumem, powodowała, że będąc ciekawy świata był zarazem pokorny, gdyż potrafił słuchać i uczyć się od innych. Podziwiając młodszych kolegów i koleżanki, nie tylko okazywał im wsparcie, lecz także był autentycznie gotowy studiować ich teksty, by dowiedzieć się czegoś nowego i przyjać inne spojrzenie na świat. Będąc otwartym na dialog $\mathrm{z}$ inaczej wierzącymi i niewierzącymi, potrafił również wsłuchiwać się w głos agnostyków, doszukując się w tym, co oni prezentują, ich autentycznego głodu prawdy. Ks. Mroczkowski obdarowany łaską wiary i doświadczony spotkaniami z ludźmi inaczej myślącymi, nie przejmował ich poglądu na świat, ale potrafił tak cudownie słuchać, że człowiek w jego obecności mógł wybrzmieć w pełni swej tożsamości. Pozostając sobą, Profesor z Płocka był gotowy zniżyć się do swego słuchacza, co potwierdza jego personalizm, nad którym tak zapamiętale reflektował, szukając głębszego zrozumienia natury osoby ludzkiej.

W duchu odnowionej teologii moralnej zbierał on dane z nauk szczegółowych o człowieku i układał $\mathrm{w}$ przejrzysty schemat dostarczony przez adekwatną antropologię teologicznomoralną. Postrzegał świat i człowieka oczyma kogoś, kto szukał sensu istnienia, bo karmiąc się słowem Bożym i trwając w sakramentalnej strukturze Kościoła, głęboko wierzył w ten sens, gdyż został on objawiony przez Boga. Okazując wrażliwość na dobro i piękno, Mroczkowski chciał je dostrzegać w najmniejszych przejawach ludzkich zachowań, w których odbija się obraz Tego, który wszystko stworzył.

Taka postawa badawcza, w której z dociekliwością i dopracowanym warsztatem metodologicznym łączyła się wielkoduszna życzliwość i wyrozumiała uprzejmość wobec człowieka, prowadziła ks. Ireneusza do podejmowania tematów ważnych, a nawet niekiedy drażliwych dla Kościoła i świata. W tym

\footnotetext{
${ }^{53}$ Por. Anna Janiszewska, „Chrześcijańska troska ekologiczna w nauczaniu ks. Ireneusza Mroczkowskiego", w Dyscyplina rozumu i uczciwość serca, 241-55.
} 
ujawniała się jego odwaga i otwartość na krytykę, które cechowały jego twórczość i odsłaniały jego dążenie do odkrycia prawdy za cenę pochylenia się przed jej świadkami. Z życzliwego zainteresowania życiem Kościoła jako wspólnoty oraz wnikania w losy poszczególnego człowieka, rodził się zapał organizacyjny, wyrażający się we włączaniu w różne inicjatywy naukowe i duszpasterskie. Pasją ks. Mroczkowskiego było animowanie ludzi do zespołowego działania i cieszenie się wydobytym dobrem oraz objawionym blaskiem prawdy.

\section{BIBLIOGRAFIA}

Brzeziński, Daniel. „Działalność ks. Ireneusza Mroczkowskiego w Towarzystwie Naukowym Płockim". W Dyscyplina rozumu i uczciwość serca. Ks. Ireneusza Mroczkowskiego (19492020) sposób uprawiania teologii moralnej, red. Andrzej Derdziuk, Wojciech Kućko, 94103. Lublin: Towarzystwo Naukowe KUL, 2020.

Derdziuk, Andrzej. „Inicjator opracowywania podręcznika teologii moralnej”. W Dyscyplina rozumu i uczciwość serca. Ks. Ireneusza Mroczkowskiego (1949-2020) sposób uprawiania teologii moralnej, red. Andrzej Derdziuk, Wojciech Kućko, 149-62. Lublin: Towarzystwo Naukowe KUL, 2020.

Derdziuk, Andrzej. „Życiorys naukowy ks. Ireneusza Mroczkowskiego”. W Dyscyplina rozumu i uczciwość serca. Ks. Ireneusza Mroczkowskiego (1949-2020) sposób uprawiania teologii moralnej, red. Andrzej Derdziuk, Wojciech Kućko, 23-33. Lublin: Towarzystwo Naukowe KUL, 2020.

Gocko, Jerzy. „O etyczny i teologiczny wymiar praw człowieka. Rozważania na kanwie badań ks. Ireneusza Mroczkowskiego nad prawami człowieka". W Dyscyplina rozumu i uczciwość serca. Ks. Ireneusza Mroczkowskiego (1949-2020) sposób uprawiania teologii moralnej, red. Andrzej Derdziuk, Wojciech Kućko, 163-77. Lublin: Towarzystwo Naukowe KUL, 2020.

Góralczyk, Paweł. Ocena całokształtu dorobku naukowego ks. dr hab. Ireneusza Mroczkowskiego. Archiwum KUL.

Góralczyk, Paweł. Recenzja dorobku naukowego ks. dr. Ireneusza Mroczkowskiego. Archiwum KUL.

Góralski, Wojciech. „Kompetentnie, z oddaniem i wytrwałością. Ks. Ireneusz Mroczkowski jako rektor Wyższego Seminarium Duchownego w Płocku (1999-2005)”. W Dyscyplina rozumu i uczciwość serca. Ks. Ireneusza Mroczkowskiego (1949-2020) sposób uprawiania teologii moralnej, red. Andrzej Derdziuk, Wojciech Kućko, 67-81. Lublin: Towarzystwo Naukowe KUL, 2020.

Greniuk, Franciszek. „Kronika Sekcji Teologii Moralnej KUL za rok 1978-1979”. Roczniki Teologiczno-Kanoniczne 2, z. 3(1980): 97-8.

Grzybowski, Michał Marian. Ksiadz prałat Czestaw Chojecki proboszcz i dziekan w Rypinie. Płock: Płocki Instytut Wydawniczy, 2005.

Janiszewska, Anna. „Chrześcijańska troska ekologiczna w nauczaniu ks. Ireneusza Mroczkowskiego". W Dyscyplina rozumu i uczciwość serca. Ks. Ireneusza Mroczkowskiego (1949- 
2020) sposób uprawiania teologii moralnej, red. Andrzej Derdziuk, Wojciech Kućko, 24155. Lublin: Towarzystwo Naukowe KUL, 2020.

Janiszewska, Anna i Wojciech Kućko. „Bibliografia prac ks. Ireneusza Mroczkowskiego”. W Dyscyplina rozumu i uczciwość serca. Ks. Ireneusza Mroczkowskiego (1949-2020) sposób uprawiania teologii moralnej, red. Andrzej Derdziuk, Wojciech Kućko, 35-52. Lublin: Towarzystwo Naukowe KUL, 2020.

Janiszewska, Anna i Wojciech Kućko. „Ks. Ireneusz Mroczkowski - promotor prac magisterskich i doktorskich, recenzent w przewodach doktorskich, habilitacyjnych i profesorskich”. W Dyscyplina rozumu i uczciwość serca. Ks. Ireneusza Mroczkowskiego (1949-2020) sposób uprawiania teologii moralnej, red. Andrzej Derdziuk, Wojciech Kućko, 53-66. Lublin: Towarzystwo Naukowe KUL, 2020.

Juros, Helmut. Recenzja rozprawy habilitacyjnej ks. dr. Ireneusza Mroczkowskiego. Archiwum KUL.

Kosek, Mirosław. „W trosce o Kościół partykularny. Ks. Ireneusz Mroczkowski jako redaktor naczelny «Studiów Płockich»". W Dyscyplina rozumu i uczciwość serca. Ks. Ireneusza Mroczkowskiego (1949-2020) sposób uprawiania teologii moralnej, red. Andrzej Derdziuk, Wojciech Kućko, 105-15. Lublin: Towarzystwo Naukowe KUL, 2020.

Kućko, Wojciech. „Interpretacja teologii ciała św. Jana Pawła II w twórczości ks. Ireneusza Mroczkowskiego". W Dyscyplina rozumu i uczciwość serca. Ks. Ireneusza Mroczkowskiego (1949-2020) sposób uprawiania teologii moralnej, red. Andrzej Derdziuk, Wojciech Kućko, 193-209. Lublin: Towarzystwo Naukowe KUL, 2020.

Machinek, Marian. „Teologia moralna wobec genderyzmu. Refleksja na kanwie publikacji ks. Ireneusza Mroczkowskiego". W Dyscyplina rozumu i uczciwość serca. Ks. Ireneusza Mroczkowskiego (1949-2020) sposób uprawiania teologii moralnej, red. Andrzej Derdziuk, Wojciech Kućko, 211-24. Lublin: Towarzystwo Naukowe KUL, 2020.

Marcol, Alojzy. Ocena całoksztattu dorobku naukowego ks. dr hab. Ireneusza Mroczkowskiego. Archiwum KUL.

Mroczkowski, Ireneusz. „«Nowy feminizm» w nauczaniu Jana Pawła II”. Roczniki Teologiczne 10(2006): 213-24.

Mroczkowski, Ireneusz. Działalność organizacyjna $i$ wychowawcza. Archiwum KUL.

Mroczkowski, Ireneusz. „Anioł i niedzielne popołudnie”. Dostęp 16.02.2014. https://www.die cezjaplocka.pl/blogi/ireneusz-mroczkowski/.

Mroczkowski, Ireneusz. Autoreferat o zainteresowaniach, osiagnięciach $w$ działalności naukowo-badawczej oraz w ksztattowaniu kadr naukowych. Lublin 28.11.2000. Archiwum KUL.

Mroczkowski, Ireneusz. „Bociany”. Dostęp: 19.08.2012. https://www.diecezjaplocka.pl/blogi /iren eusz-mroczkowski/.

Mroczkowski, Ireneusz. „Czarnobylska modlitwa”. Dostęp 5.12.2015. https://www.diecezjaplo cka.pl/blogi/ireneusz-mroczkowski/.

Mroczkowski, Ireneusz. „Dziękuję Ci Księże Rektorze”. Dostęp 20.02.2018. https://www.diece zjaplocka.pl/blogi/ireneusz-mroczkowski/.

Mroczkowski, Ireneusz. „Jak przepowiadać w godzinie próby?” Dostęp 27.12.2018. https://www.diecezjaplocka.pl/blogi/ireneusz-mroczkowski/.

Mroczkowski, Ireneusz. „Krzyż w Porębie Żegoty”. Dostęp 16.03.2012. https://www.diecezja plocka.pl/blogi/ireneusz-mroczkowski/.

Mroczkowski, Ireneusz. „Łyżeczka miodu”. Dostęp 15.09.2012. https://www.diecezjaplocka. pl/blogi/ireneusz-mroczkowski/.

Mroczkowski, Ireneusz. „Moi mistrzowie - kapłani”. Dostęp 7.04.2012. https://www.diecezja plocka.pl/blogi/ireneusz-mroczkowski/. 
Mroczkowski, Ireneusz. „Moje Soplicowo”. Dostęp 14.07.2012. https://www.diecezjaplocka.pl/ blogi/ireneusz-mroczkowski/.

Mroczkowski, Ireneusz. „Nikt nie woła?”. Dostęp 9.08.2016. https://www.diecezjaplocka.pl/blo gi/ireneusz-mroczkowski/.

Mroczkowski, Ireneusz. Natura osoby ludzkiej. Podstawy tożsamości człowieka. Płock: Płocki Instytut Wydawniczy, 2012.

Mroczkowski, Ireneusz. „Nowa Wielka Nowenna? Zarys programu obrony rodziny w Polsce”. Teologia i Moralność 4(2008): 183-92.

Mroczkowski, Ireneusz. „Od Matki Bożej Brzemiennej do Matki Bożej Bolesnej”. Dostęp 29.05.2012. https://www.diecezjaplocka.pl/blogi/ireneusz-mroczkowski/.

Mroczkowski, Ireneusz. „Ojcowskie święcenie”. Dostęp 10.04.2012. https://www.diecezjaploc $\mathrm{ka}$.pl/blogi/ireneusz-mroczkowski/.

Mroczkowski, Ireneusz. Osoba i cielesność. Moralne aspekty teologii ciała. Płock: Płocki Instytut Wydawniczy, 1994.

Mroczkowski, Ireneusz. „Otwarta przestrzeń po zmarłych”. Dostęp 31.10.2013. https://www. diecezjaplocka.pl/blogi/ireneusz-mroczkowski/.

Mroczkowski, Ireneusz. „Panno święta, co Jasnej bronisz Częstochowy”. Dostęp 8.06.2015. https://www.diecezjaplocka.pl/blogi/ireneusz-mroczkowski/.

Mroczkowski, Ireneusz. „Szkoła w Rzewniu”. Dostęp 31.08.2012. https://www.diecezjaplocka. pl/blogi/ireneusz-mroczkowski/.

Mroczkowski, Ireneusz. Wdzięczność i nadzieja. Przemówienia rektorskie 1999-2005. Płock: Płocki Instytut Wydawniczy, 2007.

Mroczkowski, Ireneusz. „Z dobrą wiarą wobec wątpiących”. Dostęp 29.03.2017. https://www. diecezjaplocka.pl/blogi/ireneusz-mroczkowski/.

Mroczkowski, Ireneusz. „Z miłości Zbawiciela. Moje ikony Jezusa”. Dostęp 10.03.2019. https:// www.diecezjaplocka.pl/blogi/ireneusz-mroczkowski/.

Mroczkowski, Ireneusz. „Zapach Wiecznie Żyjącego”. Dostęp 15.08.2014. https://www.diece zjaplocka.pl/blogi/ireneusz-mroczkowski/.

Mroczkowski, Ireneusz. Zto i grzech. Studium filozoficzno-teologiczne. Lublin: RW KUL, 2000.

Mroczkowski, Ireneusz. „Zło radykalne w ujęciu I. Kanta”. Studia Ptockie 25(1997): 99-107.

Mroczkowski, Ireneusz. „Zło w ujęciu P. Ricoeura”. Roczniki Teologiczne 47, z. 3(2000): 31-45.

Nagórny, Janusz. Ocena rozprawy habilitacyjnej i dorobku naukowego ks. dr. Ireneusza Mroczkowskiego. Archiwum KUL.

Nagórny, Janusz. Recenzja dorobku naukowego i osiagnięć dydaktycznych ks. dr. hab. Ireneusza Mroczkowskiego. Archiwum KUL.

Niedźwiecki, Marek. Odnowa i rozwój polskiej teologii moralnej po Soborze Watykańskim II. Kraków: Wydawnictwo UNUM, 2002.

Rujner, Agata. „Małżeństwo i rodzina w perspektywie nadziei”. W Dyscyplina rozumu i uczciwość serca. Ks. Ireneusza Mroczkowskiego (1949-2020) sposób uprawiania teologii moralnej, red. Andrzej Derdziuk, Wojciech Kućko, 305-18. Lublin: Towarzystwo Naukowe KUL, 2020.

Stacherski, Remigiusz. „Rola katolików świeckich w odnowie Kościoła Płockiego w publikacjach i działalności ks. Ireneusza Mroczkowskiego”. W Dyscyplina rozumu i uczciwość serca. Ks. Ireneusza Mroczkowskiego (1949-2020) sposób uprawiania teologii moralnej, red. Andrzej Derdziuk, Wojciech Kućko, 83-94. Lublin: Towarzystwo Naukowe KUL, 2020.

Zadroga, Adam. „Moralne aspekty przedsiębiorczości, bogactwa i kariery w ujęciu ks. Ireneusza Mroczkowskiego". W Dyscyplina rozumu i uczciwość serca. Ks. Ireneusza Mroczkowskiego (1949-2020) sposób uprawiania teologii moralnej, red. Andrzej Derdziuk, Wojciech Kućko, 257-67. Lublin: Towarzystwo Naukowe KUL, 2020. 
Zadroga, Adam. „Teologia moralna na Katolickim Uniwersytecie Lubelskim Jana Pawła II”. W Polska teologia moralna czterdzieści lat po Soborze Watykańskim II, red. Janusz Nagórny, Jerzy Gocko, 197-206. Lublin: Gaudium, 2006.

Zadykowicz, Tadeusz. „Ks. Ireneusz Mroczkowski - Autor bloga”. W Dyscyplina rozumu i исzciwość serca. Ks. Ireneusza Mroczkowskiego (1949-2020) sposób uprawiania teologii moralnej, red. Andrzej Derdziuk, Wojciech Kućko, 117-45. Lublin: Towarzystwo Naukowe KUL, 2020.

KS. IRENEUSZ MROCZKOWSKI (1949-2020)

TEOLOG MORALISTA

St res z c z e n i e

Ks. Ireneusz Mroczkowski (1949-2020) był teologiem moralistą zatrudnionym na KUL oraz na UKSW i innych uczelniach akademickich. Był aktywnym uczestnikiem życia Kościoła w Płocku jako rektor seminarium, członek Płockiego Towarzystwa Naukowego oraz redaktor „Studiów Płockich”. Pełnił posługę przewodniczącego Stowarzyszenia Teologów Moralistów w Polsce. W swojej twórczości naukowej zajmował się metodologią uprawiania nauki, antropologią teologicznomoralną, teologią ciała, małżeństwem i rodziną, feminizmem, prawami człowieka, moralnością życia społeczno-politycznego oraz ekologią. Zabierał też głos w sprawach wychowania seminaryjnego, kondycji Kościoła w Polsce, powołania i posłannictwa świeckich we współczesnym Kościele oraz aktualnego stanu świadomości moralnej. Był dobrym człowiekiem, który łączył prostą wiarę z dyscypliną rozumu i uczciwością serca.

Słowa kluczowe: Ireneusz Mroczkowski; teologia moralna; historia teologii moralnej; antropologia. 